ENTREPRENEURSHIP AND SUSTAINABILITY ISSUES

ISSN 2345-0282 (online) http://jssidoi.org/jesi/

2020 Volume 7 Number 3 (March)

http://doi.org/10.9770/jesi.2020.7.3(4)

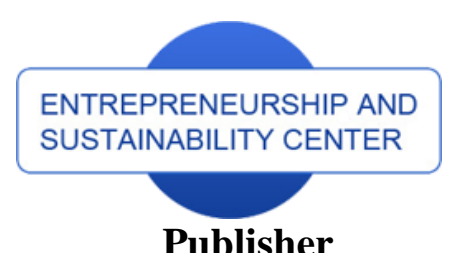

Publisher

http://jssidoi.org/esc/home

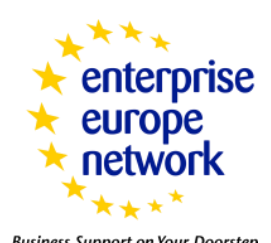

Business Support on Your Doorstep

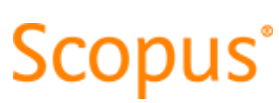

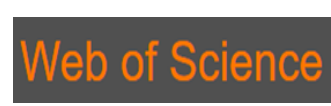

1) Clarivate

\title{
SCIENTIFIC PRIORITIES AND REAL PROSPECTS FOR COST OPTIMIZATION IN FORMULATION DEVELOPMENT
}

\author{
G.T. Glembotskaya ${ }^{1}$, S.Yu. Eremin ${ }^{2}$, E.E. Chupandina ${ }^{3}$ \\ ${ }^{1,2}$ Sechenov First Moscow State Medical University (Sechenov University), Moscow, Bolshaya Pirogovskaya Street, 19, Bld. \\ 1, Moscow, 119146, Russia \\ ${ }^{3}$ Voronezh State University, Universitetskaya Sq., 1, Voronezh, 394018, Russia \\ E-mails:1 glembotskaya@rambler.ru; ${ }^{2}$ stas_16_06_92@mail.ru
}

Received 16 March 2019; accepted 20 December 2019; published 30 March 2020

\begin{abstract}
As a result of the systematic structural analysis of the collected scientific data on the problem under study, the trends in the development of the pharmaceutical sector that have established in the global space, including the Russian Federation, have been marked, the changes in the modern healthcare systems have been noted, and it has been proven that the problem of finding accelerated and efficient methods of drug development that meet the interests of all stakeholders needs the priority solution. The structure of distributing the clinical studies of drugs in the world practice has been presented, and data on the funds for the development of the main stages of the process under study and therapeutic groups of drugs for various nosologies have been presented. The main difficulties of objective assessment of the formulation development costs have been defined, the influencing factors have been identified, and the methodical approach to calculating the resources spent has been proposed. The results have been summarized, and the prospects for the rational use of the advanced information technologies for the development and support of innovative domestic developments in the pharmaceutical sector have been demonstrated. As a result of the research into the scientific data, a real opportunity to optimize the costs of developing innovative drugs through their repositioning has been demonstrated for the first time, the conceptual methodical approach to solving the identified problems has been justified, and prospects for its implementation have been outlined, with due consideration for the further development of the pharmaceutical market and the introduction of personalized pharmaceutical care. The study has been conducted on the basis of systematic analytical structuring of the information data and the results of independent research with the identification of global trends and the determination of practical significance, as well as scientific perspectives in the field under study.
\end{abstract}

Keywords: drug development; stages of development; efficiency of phases of clinical studies; capabilities of Artificial Intelligence in the development; cost optimization; repositioning of drugs

Reference to this paper should be made as follows: Glembotskaya, G.T., Eremin, S.Yu., E.E. Chupandina, E.E. 2020. Scientific priorities and real prospects for cost optimization in formulation development. Entrepreneurship and Sustainability Issues, 7(3), 14841499. https://doi.org/10.9770/jesi.2020.7.3(4)

JEL Classifications: O31

\section{Relevance}

The scientists and experts in the modern global scientific community note that the majority of states recognize the pharmaceutical industry as a priority for the innovation-driven growth of the country. Along with this, there are a slowdown in the average annual growth rate of $R \& D$ costs and a decrease in the growth rate of the original drug 


\section{ENTREPRENEURSHIP AND SUSTAINABILITY ISSUES}

ISSN 2345-0282 (online) http://jssidoi.org/jesi/

2020 Volume 7 Number 4 (March)

http://doi.org/10.9770/jesi.2020.7.3(4)

segment, with a simultaneous growth in the generics segment (Sholomitskaya, 2013). The introduction of the new and increasingly expensive drugs to the market is accompanied by long-term procedures, as well as objective and subjective risks. While subjective risks are associated with the conscious actions of the market actors, objective risks are associated with the real state of the environment of the pharmaceutical industry and the related industries. These include the general level of knowledge in the natural science and medical science, the use of technological and digital platforms in chemical and biological synthesis, etc. In this context, pharmaceutical companies seek to reduce operating costs and the length of the R\&D cycle, using various strategies for improving the efficiency and optimization of R\&D processes, including outsourcing, Big Data, strategic partnerships, business process management, etc. (Frank, Ginsberg, 2017).

Along with changes in the pharmaceutical sector, some events also occur in the systems of public healthcare caused by the rapid growth of infectious and noncommunicable diseases threatening the world community and accompanied by the emergence of promising methods of their control. The development and introduction of new medical technologies, as well as the intensive development of personalized medicine necessitate the launch of innovative drugs with proven safety and efficacy on the pharmaceutical market (World Health Organization, 2019). It is known that the drug development, including personalized drugs, is a complex, time-consuming, costly, and labor-intensive process. Therefore, the problem of finding accelerated and efficient methods of pharmaceutical development that meet the interests of all stakeholders is of priority.

Of scientific interest are the analytical systematization of various approaches used in the world practice to optimize the cost of drug development, as well as the justification of rationalization options for this process by expanding the opportunities used in the Russian economy. From this standpoint, it is necessary and relevant to determine the development trends in the pharmaceutical industry in the global space, including the Russian Federation, conduct a structural analysis of the new drug development, identify problems of objective assessment, and justify the efficient methods to reduce its cost.

Goal of the article is to carry out a structural analysis of the drug development process and its cost evaluation with the rationale of the most priority and promising scientific and practical approaches to the cost optimization in the formulation development.

The study of the modern methods for solving similar conceptual problems has allowed to formulate the following tasks to achieve the goal: 1) justify the existence of a real opportunity to optimize the cost of developing drugs that meet the needs of the modern medical practice; and 2) form a methodical approach to building informational and mathematical models for optimizing costs that are most adapted to Russian conditions, taking into account the further development of the drug market and the introduction of personalized pharmaceutical care.

The authors selected scientific methods that allowed to ensure the reliability of the results obtained in order to solve these goal tasks.

\section{Materials and methods}

The method of the study is based on the principles of the systemic structural analysis and conceptual modeling. The data from the state and departmental statistics, international analytical agencies, reports of the largest pharmaceutical companies, published results of research by Russian scientists, data from independent research, as well as information from publicly available electronic databases of international organizations (World Health Organization, World Medical Organization, International Pharmaceutical Federation), etc. were used in the course of the study. 


\section{ENTREPRENEURSHIP AND SUSTAINABILITY ISSUES}

ISSN 2345-0282 (online) http://jssidoi.org/jesi/

2020 Volume 7 Number 4 (March)

http://doi.org/10.9770/jesi.2020.7.3(4)

The study was conducted on the basis of a systematic critical review and analysis of the collected data and the results of independent research using various scientific methods: retrospective, content analysis, system analysis, process approach, computational analytical, economic statistical, logical, graphical, and modeling approach.

The critical analysis of scientific sources about the evolution of the drug development in historical sequence was carried out, and priority problems were identified using the methods of retrospective, systemic structural and content analysis. The process approach allowed analyzing the process of drug development and the results of clinical studies differentiated by the selected stages, steps, and phases. The structure of the pharmacotherapeutic focus of research in new drugs was determined during the systemic structural analysis, and the results of structuring were obtained using the calculation and analytical method by several cost criteria for the drug development. The economic and statistical methods were used to estimate rate changes in the growth/decrease in the average cost of drug development over time, and the trend established over the past decade was defined. The main factors influencing the increase in $R \& D$ costs were identified during the structured logical analysis. The results of the cost formation simulation in creating the original drug were presented using the graphical method.

\section{Results and discussion}

The critical analysis of scientific sources about the drug development evolution allowed to trace the scientific methodological approaches used to find innovative medicines, provide a situational description of the current state of this scientific and practical problem, identify the emerging challenges, and propose a conceptual approach to its solution.

According to literary data, about 4,500 companies in the world are engaged in the development of innovative medicines (new molecular units) or new biological preparations (based on proteins). The quantitative ratio of all the invented active substances in the composition is distributed as follows: $2 / 3$ are new chemical compounds, more than $1 / 10$ are substances of biological origin, and about $1 / 5$ are genetic engineering ones (Nuzhnova, Gribova, 2013). The advanced high-tech approaches involve the use of the high-throughput screening (HTS) method, the main purpose of which is to identify potential candidates by screening specialized libraries of components that have desired impact on the receptor. Such a rapid scanning of biological processes allows to quickly remove the compounds with an unsuitable or zero potential from the list of substances for analysis, and thus allows to identify potential active substances and make proposals for their optimization regarding the molecule under study. However, the screening processes are not able to assess toxicity and bioavailability of substances. As such, the results of the HTS analysis provide a starting point for further steps in the drug discovery and understanding the interaction or role of a particular biochemical process.

The biological activity is modeled at the next stage using specialized software such as Quantitative Structure Activity Relationships (QSAR), which results in the creation of a highly active substance with the lowest possible side effects and financial costs of the developer during the synthesis. QSAR is implemented using one of the following approaches: 1) direct (creating an appropriate ligand suitable for a specific receptor) and 2) reverse (selecting a receptor for the existing natural ligand). The scientific principles for implementing these two approaches are based on various technologies, such as nuclear magnetic resonance (NMR), molecular genetics, 3D modeling of the active molecule using such systems as computer assisted design (CAD). The technology of full computer simulation of chemical synthesis is also used, which allows to not only find less economically costly algorithms, but also to bypass international patents by retrosynthesis. Chematica, which is programmed by developers to comply with about 50,000 rules of synthesis, can be provided as an example of such software. Based on the reactions published in the chemical literature over the past 250 years and the findings of organic chemists, each rule informs the software which transformations are possible from any given molecule. The Chematica algorithms move through this network of options to generate synthetic routes to identified targets for defining new, efficient, and selective paths. The pharmaceutical company Merck acquired this software to 
improve its business processes in 2017 (Kolenov, 2019). As a result, the final choice of the synthesis process and design of potential biologically active substances is based on the experience, selectivity, and intuition of the researcher.

Research approaches to finding innovative medicinal substances constantly change. The elementary empirical screening has been the main method used for the existing or synthesized chemical compounds in recent decades (Figure 1).

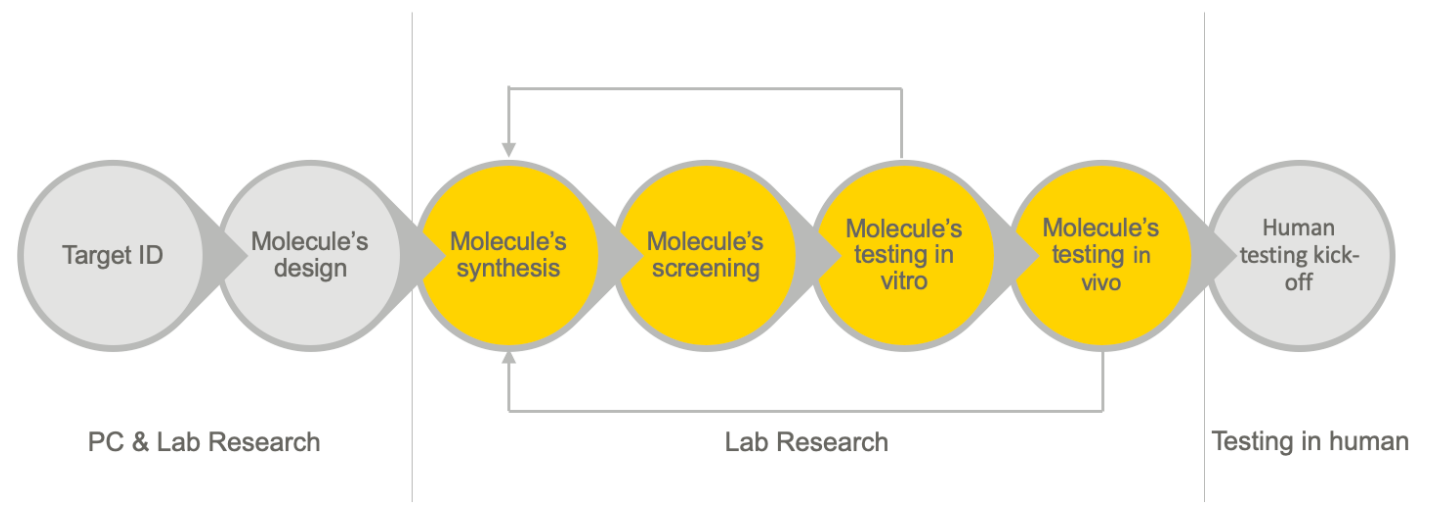

Fig. 1. Stages of the modern drug development Source: Compiled by the authors

The Russian scientist A.V. Pogrebnyak, engaged in the study of new properties of known drugs, noted that the synthesis of new substances and their pharmacological screening had been the main method of searching for drugs until recently. Only one-fourth of the total number of the known chemical compounds (more than $60 \mathrm{mln}$ ) are available for research, but their pharmacological screening cannot be realized in practice due to the high cost, since it consumes most of the funds allocated for the creation of a new original drug. Virtual screening has been extensively developing in the past fifty years due to the increased availability of computing resources, which to a certain extent can compensate for the high financial costs and labor intensity of the total pharmacological screening. The use of virtual analysis allows reducing costs as soon as at the stage of the preliminary screening, where more than $98 \%$ of the substances are screened out. Moreover, computer analysis can be used to identify a previously unrecorded pharmacological action for the already used drugs. Such an approach is economically different from the generally accepted one "synthesis first, research second", since pharmacokinetics, pharmacodynamics, and toxicity have already been studied for the known drugs, and changing their field of application does not require extensive research. This is especially relevant for certain diseases, where the search for new drugs for treatment requires great effort and financial costs (Pogrebnyak, 2013).

The transformation of the research content is evident in Figure 2. 


\section{ENTREPRENEURSHIP AND SUSTAINABILITY ISSUES}

ISSN 2345-0282 (online) http://jssidoi.org/jesi/

2020 Volume 7 Number 4 (March)

http://doi.org/10.9770/jesi.2020.7.3(4)

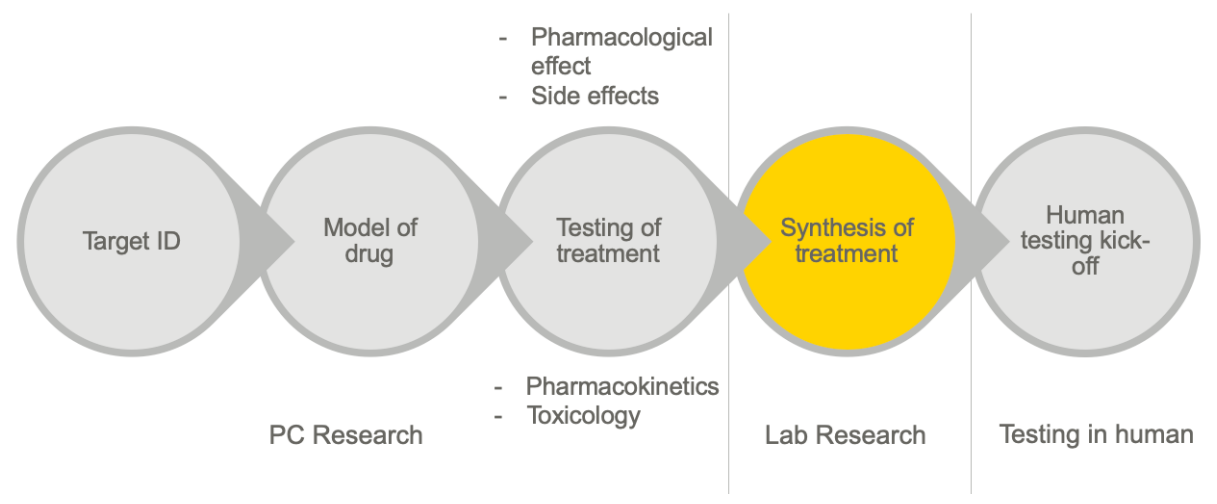

Fig. 2. Stages of the drug development using virtual models Source: compiled by the authors

The development of the modern information technologies undoubtedly makes a great contribution to the creation of innovative drugs (Kazancheva, Gerasimenko, 2016). At the same time, computer simulation does not always guarantee the drug creation since it requires a preclinical evaluation of pharmacological properties. The use of computer modeling with a wide use of advances in genomics, proteomics, molecular biology, pharmacology, and medicine promotes a more rational and efficient development, which is manifested in the targeted synthesis of drugs with given pharmacokinetic and pharmacodynamic parameters.

As a result, the final product is a result of not only the use of the latest information technologies, combination of knowledge in the various sciences and their domains, but also the rational organization of the necessary experimental research.

As such, a well-structured sequence of the drug development and research has been established by now: the process begins with finding a biologically active molecule, hypothesizing, and creating a research project to determine the therapeutic potential of the new drug (Schuhmacher et al., 2016). Then a study is conducted using the process approach method, which allows analyzing the results of individual stages of that process and noting the following features. Only after a potential candidate for the drug has been synthesized, and its structure and properties have been defined, it is possible to decide whether the drug is ready for clinical trials and move to an extensive preclinical trials on animals that provides preliminary information about efficacy, toxicity, pharmacokinetics, and safety. Wide variations in the drug dose are tested using in vitro and in vivo experiments. An in silico profile can also be implemented using the computer models of the drug-target interaction (Ayn de Jesus, 2019). As can be seen in Figure 3, about half of the candidate substances for drugs fail to pass tests at the stage of preclinical studies in testing due to low stability, teratogenicity, high mutagenicity, and many other reasons.

According to the statistics, the potential drug fails to reach the registration process in the following cases: toxicity (30\%), insufficient clinical efficacy (27\%), unacceptable safety profile (13\%), preference for other drugs $(9 \%)$, lack of further investment (5\%), and other reasons (16\%) (Belousov, 2012).

The further use of the process approach to research was aimed at identifying reserves for reducing the temporary resources. As has been shown above, $\mathrm{R} \& \mathrm{D}$ of the innovative medicines is an expensive and lengthy process consisting of a series of mandatory stages. 


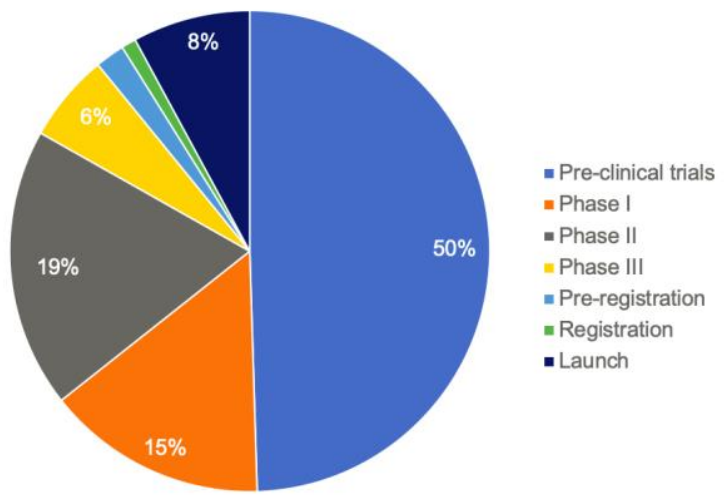

Fig. 3. Proportion of cases of abandoning the drug development at various stages, $\%$. Source: compiled by the authors

According to many researchers, it takes five to fifteen years to move from the idea to the drug introduction on the market. In general, the development of a new molecule (development, preclinical phase, subsequent clinical studies and obtaining regulatory approval) takes 11.8 years on average (Development of new drugs: how much does it actually cost?, 2014). The search for an innovative active molecule takes three to six years. According to statistics, only $2-3 \%$ of the molecules under study move to the next stage. The subsequent R\&D process of the identified substance can take up to a decade. This includes preclinical studies, which take approximately two years. Clinical studies involve four phases, three of which last from six to seven years. After this, registration and production take up to two years.

However, once the drug becomes available to consumers, phase IV of clinical trials comes, called postregistration or post-marketing. They are usually carried out after the launch of the drug sales in order to obtain more detailed information about its safety and efficacy. The results of its use in various groups of patients and with various risk factors are usually analyzed in this phase, with the detection of previously unknown and rarely encountered side effects. Along with this, new properties can be found in the already registered drug, and data for registering its new indications can be obtained, the prospects for creating a new delivery or research system and registering a new, more rational dosage form can be proposed, taking the patient's age into account, which contributes to the personalization of pharmaceutical care (Jain, 2019). Besides, the analysis of the results of registering some drugs for new indications suggests that this contributes to the reduction of the duration of the development process because certain types of clinical research become optional, and their duration may vary. The length and cost of the marketing research of the pharmaceutical company for this product are also reduced (Belousov, 2006). See Figure 4. 


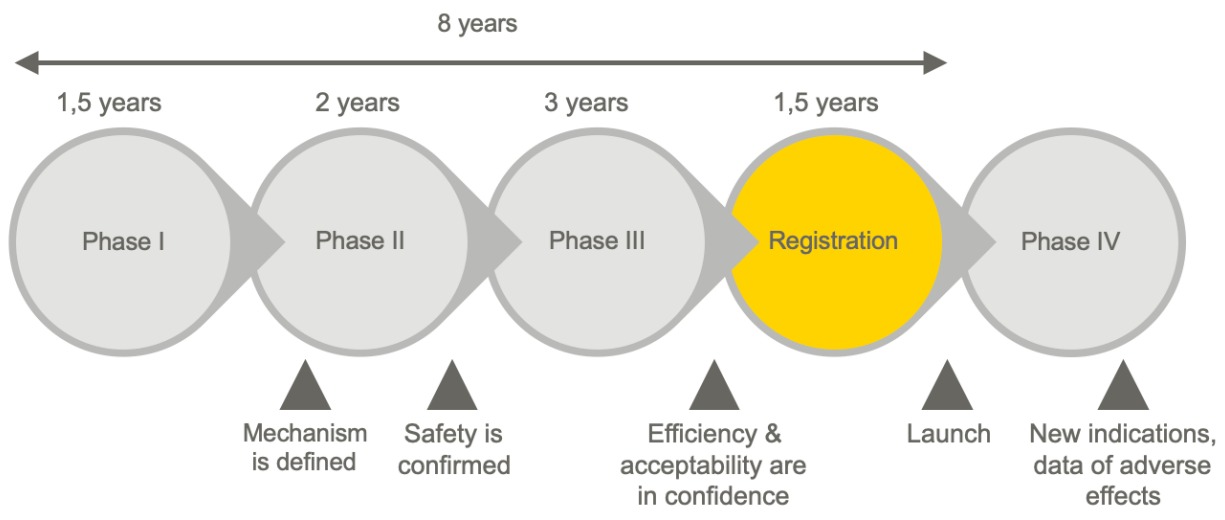

Fig. 4. Chart of the sequence of clinical studies phases, their average length and impact Source: Compiled by authors

The structure of the pharmacotherapeutic focus of research in new drugs is represented by the following data: 31 $\%$ are related to the search for drugs in oncology, $14 \%$ are related to the creation of new drugs for the treatment of various infectious diseases, and about $13 \%$ are related to scientific developments in the therapy of cardiovascular diseases. The remaining part of the structure is represented by the most relevant research in the creation of new anti-diabetic, anti-inflammatory drugs, medicines for the treatment of various mental diseases, etc. (World Health Organization, 2019). A chart of the distribution of the global clinical studies of drugs in various therapeutic groups in 2018 is represented in Figure 5, which indicates that 2/5 of all studies are conducted in oncology. Currently, most drugs are in Phases I and II of clinical studies because not all studied drugs move to the next stages.

The likelihood of a successful clinical study is subject to classification by type of disease. For example, it is relatively easy to do a blood test and monitor the efficacy and safety of a new drug in infectious diseases, but this task is much more complicated in the case of cancer or cardiac diseases.

According to statistics, the focus of all scientific research in pharmaceutical development is distributed as follows: $70 \%$ are focused on the synthesis of an innovative molecule, about $24 \%$ are aimed at identifying a new dosage form, improving dosage, etc., and the remaining $6 \%$ are studying new indications of the already existing drugs (Nuzhnova, Gribova, 2013). 
ENTREPRENEURSHIP AND SUSTAINABILITY ISSUES

ISSN 2345-0282 (online) http://jssidoi.org/jesi/

2020 Volume 7 Number 4 (March)

http://doi.org/10.9770/jesi.2020.7.3(4)

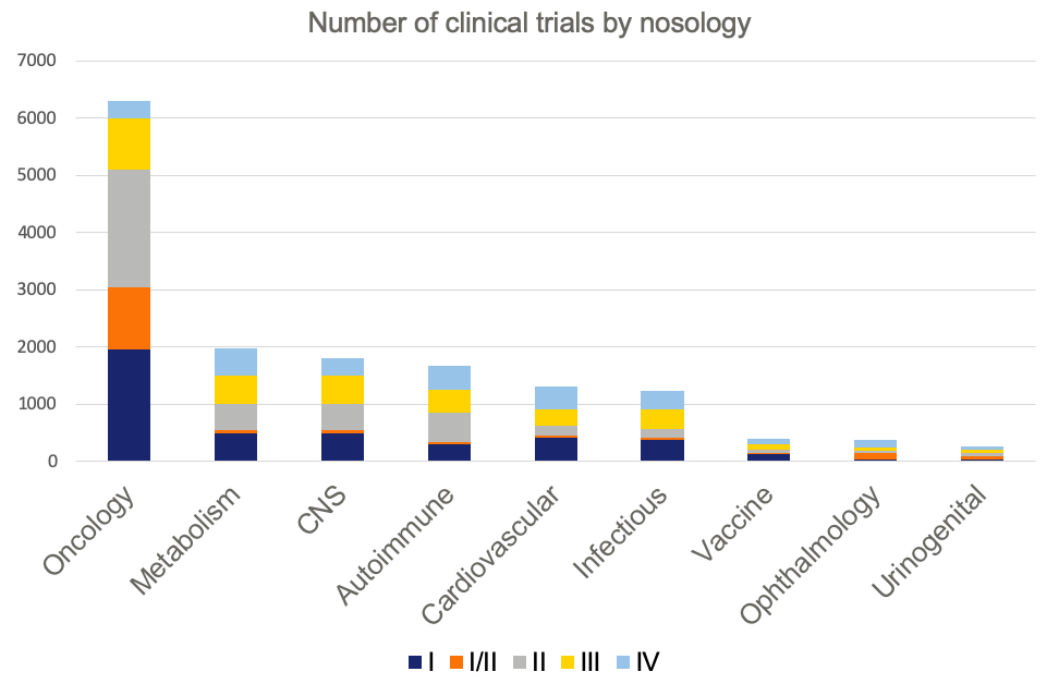

Fig. 5. Structure of the distribution of clinical studies of drugs by nosology in the world practice in terms of phases, items Source: compiled by the authors

According to the results of the express survey of 35 leading experts from a number of pharmaceutical companies, a decision on repositioning is most often based on the opinion of medical practitioners about the effects of drugs that are not presented in the instructions (57\% of the respondents), as well as the analysis of data from various clinical studies, including retrospective, observational, etc. (43\% of the respondents). The programs for repositioning drugs used in medical practice are already developed.

Repositioning allows saving hundreds of millions of US dollars by eliminating the need for a series of studies on pharmacokinetics, carcinogenicity, acute and chronic toxicity, including cardiotoxicity, nephrotoxicity, allergenicity, etc., even though the second and the third phases of clinical studies are unavoidable and costly. The research laboratories have accumulated numerous data on new therapeutic effects of the known drugs, which remain unclaimed due to the lack of investment in large-scale clinical studies. Charitable foundations are most often the main sources of funding for clinical studies on the drug repositioning. For example, the required $\$ 50$ mln to finance the "Metformin against aging" clinical study was collected by the American Federation for the Study of Aging (Pryor, Cabreiro, 2015).

The length of development of an innovative drug has the most obvious impact on the cost of the development process. The authors carried out a structured analysis of the cost of the drug development over the past decades in the course of the independent research, using the data from domestic and foreign scientific sources structured according to several criteria. It was revealed that the cost of developing an innovative drug was one of the most variable values: it ranged from $\$ 1$ bln to $\$ 11$ bln in the scientific publications of various authors. Some experts believe that pharmaceutical companies (especially large ones) try to overestimate this forecast, thus justifying high prices for new drugs. It is not beneficial for large pharmaceutical companies to make the true information about their development costs publicly available. Therefore, it is important to take into account that any estimates of the cost of developing an innovative drug can only be very approximate (Emanuel, 2019). The inconsistency in determining the cost structure for developing a new drug is one of the reasons for such a significant disagreement in cost estimates. Besides, the studies conducted in recent years most likely use databases not related to each other. 
ENTREPRENEURSHIP AND SUSTAINABILITY ISSUES

ISSN 2345-0282 (online) http://jssidoi.org/jesi/

2020 Volume 7 Number 4 (March)

http://doi.org/10.9770/jesi.2020.7.3(4)

The Tufts Center for the Study of Drug Development published the results of its research in May 2018, where the average $R \& D$ costs for innovative drugs were estimated. The resulting amount is $\$ 2.6 \mathrm{bln}$, and includes $\$ 1.4$ bln of direct investments and $\$ 1.2$ bln of an expected cash return to investors in the long-term development. Taking the cost of the post-marketing research into account, this amount increases to $\$ 3 \mathrm{bln}$. It is also noted that the likelihood of the successful completion of Phase III of clinical studies and the release of the drug to the market by regulatory authorities has almost halved over the past four years, and is no more than $12 \%$ (it was $21.5 \%$, according to the previous study in 2014) (Sullivan, 2018; Farm giants are going to use blockchain to reduce the cost of the drug development, 2018). As a result of processing the collected data, the established trend in the dynamics of the rate of growth/decrease in the average cost of the drug development over the past decade was defined. A chart presented in Figure 6 indicates their sharp growth over the past five years.

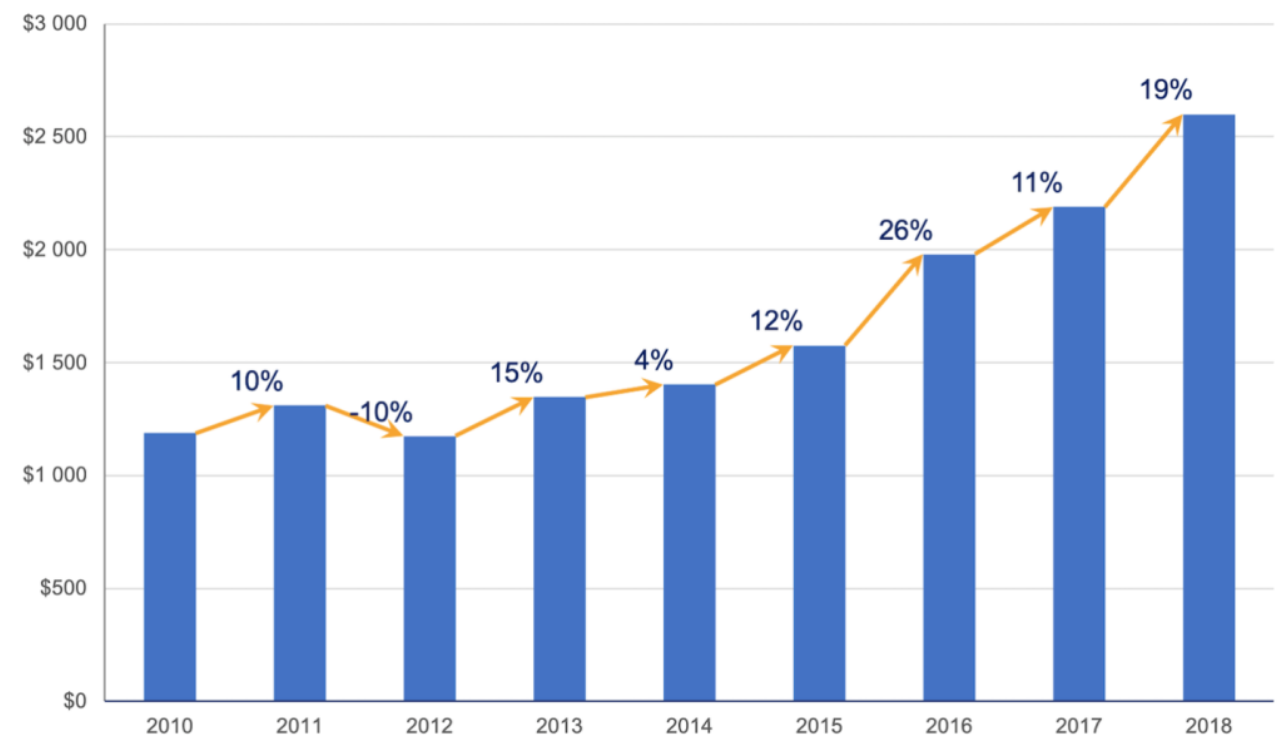

Fig. 6. Dynamics of growth in average costs for the drug development from the discovery to the market launch from 2010 to 2018 , USD mln

Source: compiled by the authors

The generalized processing of the obtained data allowed presenting the fractional structure of the phased cost distribution in the integrated form:

- $24.8 \%$ for research, development, and preclinical studies;

- $57.6 \%$ for conducting clinical trials $(57.6 \%$ were distributed among the three stages as follows: $8.1 \%$ for the first stage, $12.8 \%$ for the second stage, and $36.7 \%$ for the third stage);

- $6.4 \%$ for registration;

- $9.1 \%$ for post-marketing research; and

- $2.1 \%$ for other costs.

As can be seen in Figure 7, almost two-thirds of the costs fall on the first three phases of clinical studies, while the costs of the post-marketing research in the last phase are allocated separately (The pharmaceutical industry in figures, 2012).

Some researchers believe that the development costs can be either well below or well over $\$ 1.5$ bln, since they depend on the specifics of creating an innovative drug, including the type of disease. For example, T.A. Khonl pays special attention to the specific factors of the development cost amplitude, noting that the cost of an innovative drug varies significantly in therapeutic classes, in particular. This is due to the fact that the drug development for certain classes has an unequal probability of success in clinical studies, and the difference in the 
length of development for drugs of a certain class is even more noticeable (Khonl, 2013). Innovative drugs created to control cancer and neurological and respiratory diseases have the longest length of launch on the market.

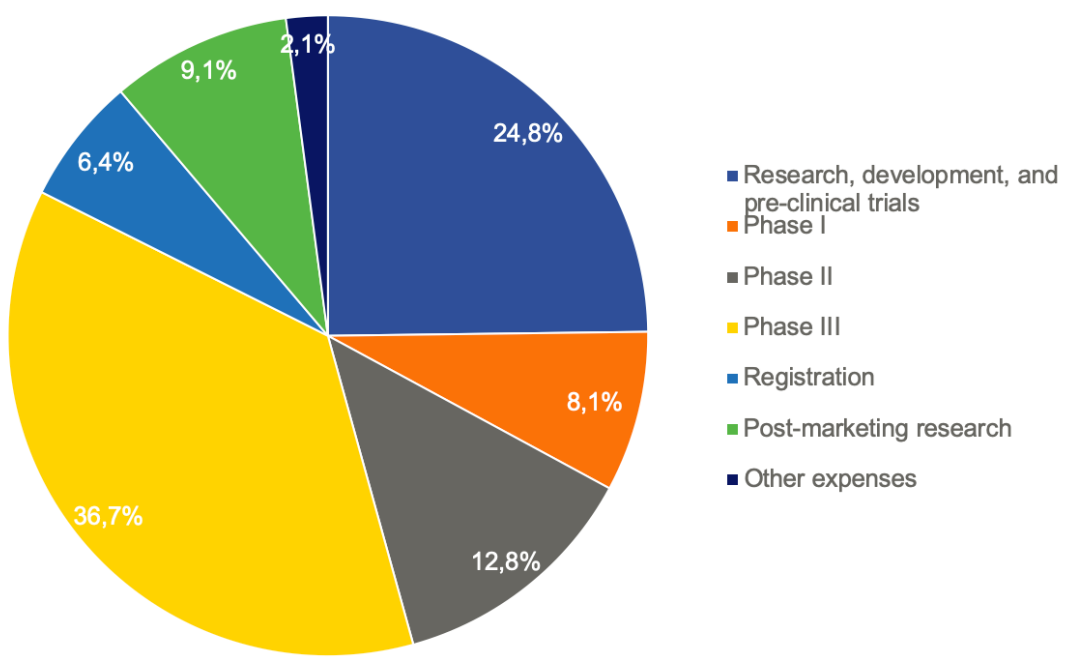

Fig. 7. Quantitative ratio of the costs of developing and introducing drugs to the market by stages, $\%$ Source: compiled by the authors

D.Yu. Belousov notes that most of the drugs are now developed in small and medium-sized companies, whose innovation costs differ significantly from Big Pharma. This became possible due to high mobility, low overhead costs, more efficient management, and high labor productivity (Belousov, 2006).

The estimated costs of developing a new drug for various therapeutic classes are presented in Table 1 (USD mln):

Table 1. Costs of developing a new drug by nosology, USD mln.

\begin{tabular}{|l|l|l|}
\hline$\#$ & Nosology & Cost, USD mln. \\
\hline 1 & & \\
\hline 2 & Blood diseases & 1,164 \\
\hline 3 & Cardiovascular diseases & 1,140 \\
\hline 4 & Gkin diseases & 870 \\
\hline 5 & HIV/AIDS & 816 \\
\hline 6 & Cancer & 694 \\
\hline 7 & Musculoskeletal diseases & 1,339 \\
\hline 8 & Neurological diseases & 1,216 \\
\hline 9 & Parasitic diseases & 1,306 \\
\hline 10 & Respiratory diseases & 583 \\
\hline 11 & Diseases of the nervous system & 1,457 \\
\hline 12 & Average value & 833 \\
\hline 13 & Standard deviation & 1,038 \\
\hline & & $\pm 289,9$ \\
\hline
\end{tabular}

Source: compiled by the authors

According to the Investopedia information financial base, pharmaceutical companies spend about $17 \%$ of their income on R\&D on average, which puts the industry in the top by this indicator (Kenton, 2018). 


\section{ENTREPRENEURSHIP AND SUSTAINABILITY ISSUES}

ISSN 2345-0282 (online) http://jssidoi.org/jesi/

2020 Volume 7 Number 4 (March)

http://doi.org/10.9770/jesi.2020.7.3(4)

A structured analysis of the use of approaches to optimize the cost of developing innovative drugs used in the domestic and foreign science and practice gives grounds to identifying the key factors influencing the growth in R\&D costs:

- increase in the number of "unsuccessful" molecules (up to $50 \%$ ), the efficiency of which failed to prove at the stage of preclinical studies;

- current trend to increase the number and length of the studies, including research for marketing purposes;

- priority of the drug development for chronic and degenerative diseases that require longer clinical studies, due to the need of longer administration to achieve the result and a more careful study to detect delayed side effects;

- increased commercialization of research (companies more often have to pay for access to research results that were publicly available in previous years);

- increase in the average length of the preclinical studies phase;

- increase in the share of extended international multicenter clinical studies;

- focus on biotechnological drugs that are more difficult to create and study; and

- reduction of the state funding of pharmaceutical R\&D.

As a result of the study, the authors have identified the real reserves to reduce the influence of some factors listed above. In recent years, cooperation has become one of the key adaptation factors for the development and solution of some problems in the pharmaceutical industry. The outdated patents, complex diseases, tough regulatory environment, and new technologies are just some of the reasons why individual pharmaceutical companies enter all sorts of collaborations with $\mathrm{R} \& \mathrm{D}$ laboratories, research institutions, non-profit organizations, and even competitors (Buvailo, 2018; Motlagh, 2018).

Transformation of the R\&D through a number of innovative technologies plays a major role in optimizing the development costs. These include Artificial Intelligence, real data, robotic and cognitive automation, social networks, mobile devices and telemedicine, which have the potential to improve the research design and decision making, simplify the recruitment of doctors and patients, and improve the efficiency and accuracy of repetitive tasks, up to submitting information to regulators. The modern technologies can lead to a dynamic and sustainable progress in the pharmaceutical industry, focused on achieving high values that are important for the future of global healthcare (Eremin, Glembotskaya, 2019). According to many experts, the industrialization of innovative technologies in biopharmaceutics will lead to numerous transformational changes in the operation of the industry, especially in R\&D (World Economic Forum, 2017).

A more detailed study of the results of using the capabilities of the Artificial Intelligence by global biopharmaceutical companies indicated that the algorithms presented in its applications were capable of analyzing large amounts of data from such sources as reports on preclinical and clinical studies, medical records, and genetic profiles. It is able to recognize patterns and trends within these data and develop hypotheses much faster than the researchers. Possessing an extensive array of information on drugs and research results, the Artificial Intelligence quickly analyzes the available information and provides assistance to researchers with the search and new ideas.

Since the traditionally used method of screening a large number of compounds and molecules to identify potential candidates is a long and expensive process, the Artificial Intelligence is potentially able to carry out this process faster and at a lower cost through the classification of drugs into categories of therapeutic use with a high degree of accuracy. It is important to note that even incorrect answers given by the Artificial Intelligence can be useful because they can identify the secondary use (properties) of a drug that scientists would not have considered (Conroy, Conroy, 2019).

The above advantages of innovative technologies are aimed at optimizing the development costs and contribute to the active transformation of the R\&D processes in the pharmaceutical sector of the economy in the country. 
The analytical generalization of the scientific data indicated that the costs of developing innovative drugs could be significantly lower in Russia than in the US and Europe because the Russian government supports domestic producers. The deployment of the modern domestic R\&D system is facilitated by a mechanism of the competitive targeted funding for economic agents by the state, which allows the former concentrating on the most promising areas (development of innovative antibiotics, orphan drugs, and bioprinting of tissues and organs) (Global Data, 2017; Jena, 2018).

The studies of the authors are systemic, and the results obtained are basic for modeling the process of optimizing the costs of the drug development (Glembotskaya, Ivanov, 2017; Glembotskaya, Eremin, 2019). They build the basis for the formation of an algorithm for a conceptual methodical approach to a more differentiated step-by-step estimation of the costs of the development, research, and launch of a drug on the market (Figure 8).

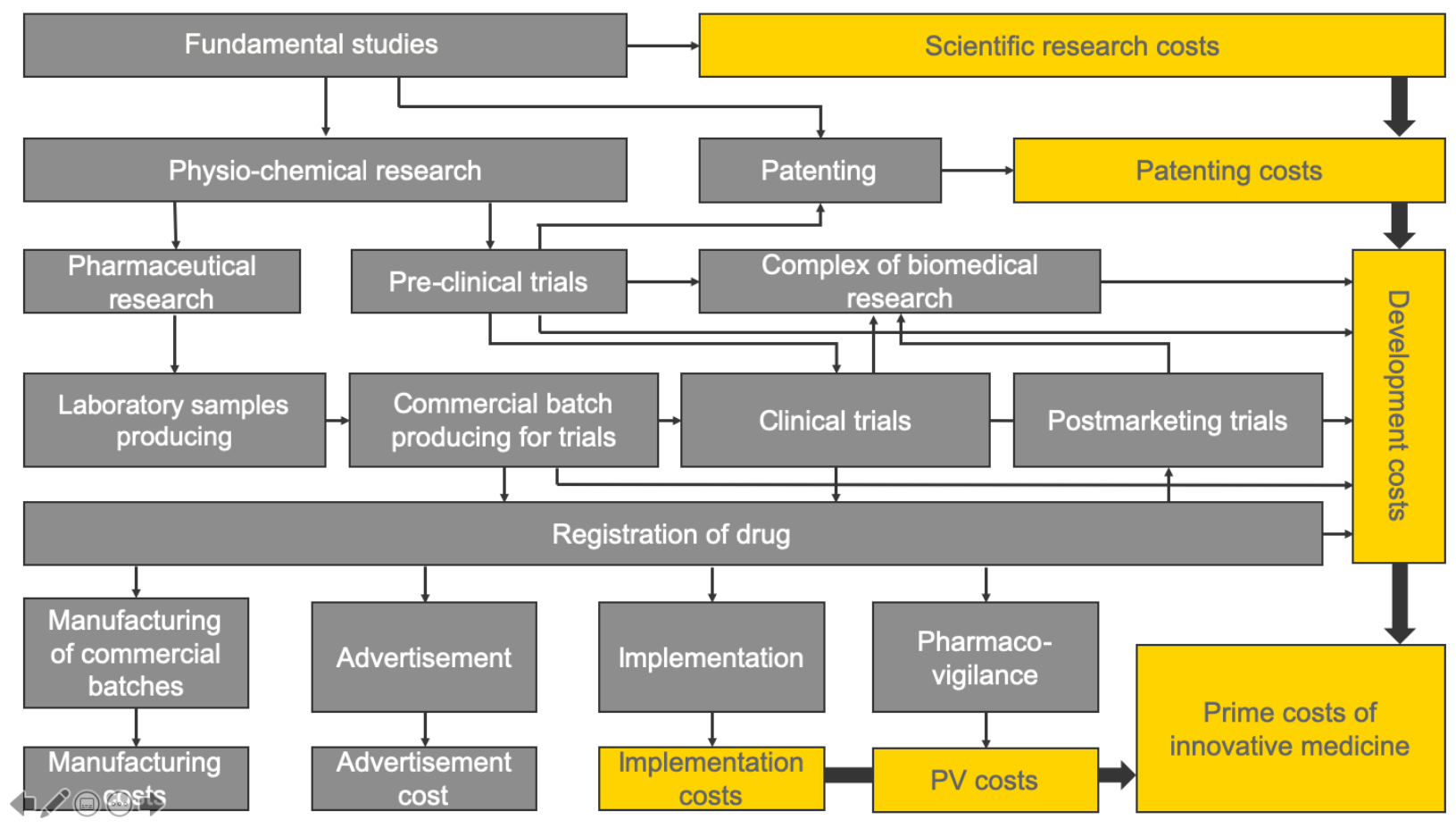




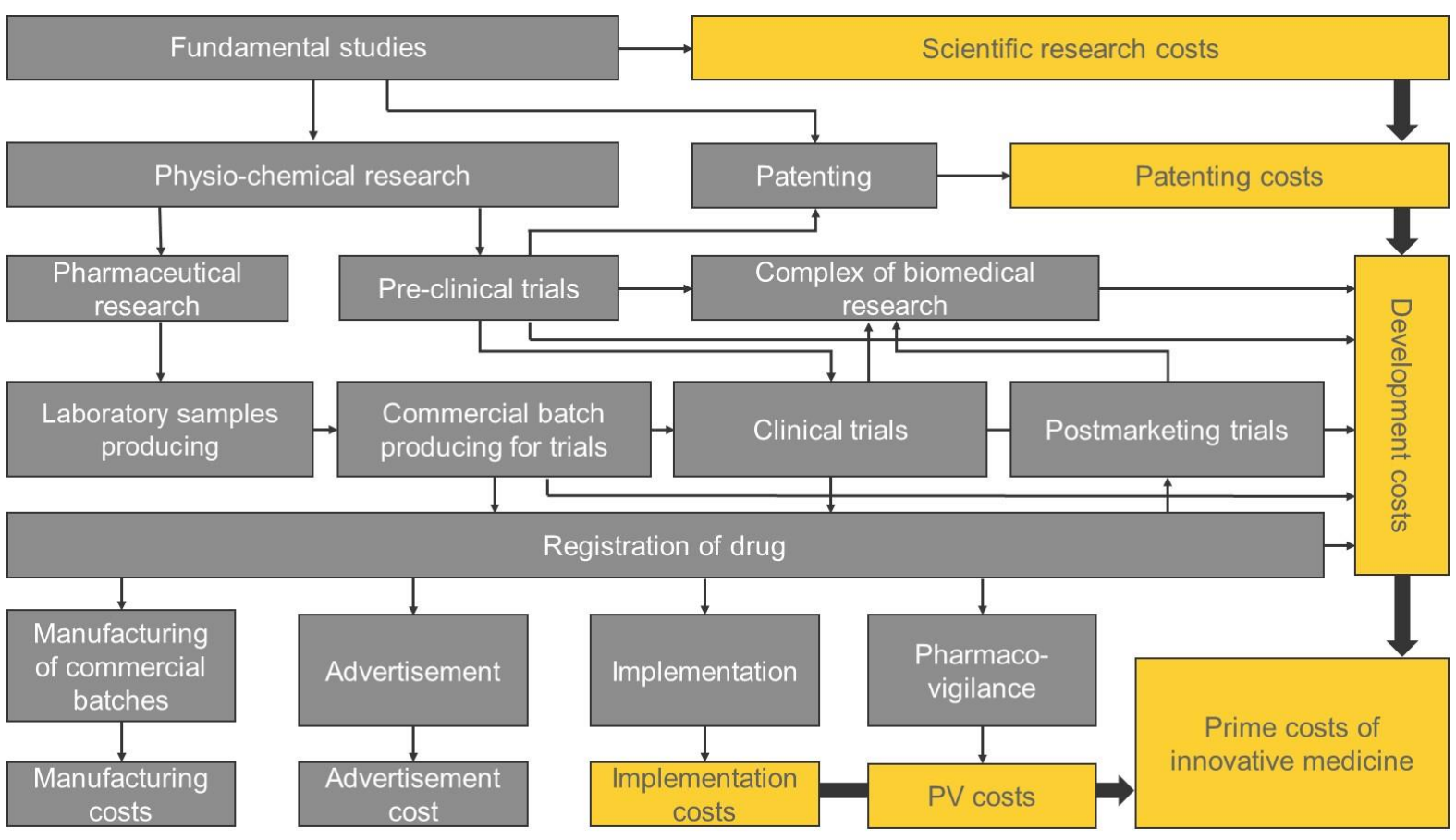

Fig. 8. Model chart of the cost formation when creating the original drug Source: compiled by the authors

The further plans of research include the development of a transformed model for optimizing the costs of the pharmaceutical development, taking into account the domestic drug market development, including new paradigms for creating innovative drugs and personalization technology, which is intended for use by pharmaceutical companies as a tool for the rational resource planning. A promising area in mobilization of the identified reserves of reducing the length and cost of pharmaceutical development is a wider use of the advanced information technologies based on the formation of the appropriate scientific basis.

\section{Conclusions}

1. The structured analysis of the scientifically justified approaches existing in the world practice to optimize the cost of the drug development has been carried out. The amounts of the consumed funds have been analyzed in terms of the main stages of the process under study and therapeutic groups of drugs for different nosologies. The key difficulties of the objective evaluation of the pharmaceutical development costs have been defined, and the influencing factors have been identified.

2. The scientific and practical approaches to the drug development cost reduction that are most adapted to the Russian conditions and corresponding to the scientific level and the needs of the modern medical practice have been identified, taking into account the prevailing global trends in the pharmaceutical market. The list of factors contributing to higher costs for pharmaceutical development has been formed, and real reserves for their reduction have been identified, taking into account the specifics of the domestic R\&D system development, which necessitates the development of cooperation and transformation of processes through a number of innovative technologies.

3. The real opportunity to optimize the costs of the drug development in order to make rational use of the R\&D funds by pharmaceutical manufacturers has been theoretically justified and demonstrated by scientific evidence, which will ultimately contribute to providing the modernized personalized medical and pharmaceutical aid to the 


\section{ENTREPRENEURSHIP AND SUSTAINABILITY ISSUES}

ISSN 2345-0282 (online) http://jssidoi.org/jesi/

2020 Volume 7 Number 4 (March)

http://doi.org/10.9770/jesi.2020.7.3(4)

population. It has been proven that the priority way to reduce the cost of the drug development is the careful formulation and implementation of post-marketing research programs by pharmaceutical companies, during which there is a real opportunity to identify additional effects of drugs and to reposition them.

4. A scientifically proven prospect of optimizing the cost of developing highly efficient and safe drugs with high social significance through repositioning is not only described by scientific novelty for the first time, but also has a practical focus. The prospects for the further development of the conducted research to solve the problem of finding accelerated and efficient methods of the drug development by domestic and international scientific community have been revealed.

\section{References}

Ayn de Jesus. 2019. Artificial Intelligence in the Pharmaceutical industry - An Overview of Innovations. Emerj. https://emerj.com/aisector-overviews/artificial-intelligence-for-pharmacies-an-overview-of-innovations/

Belousov D.Yu. 2012. Stoimost razrabotki innovatsionnykh lekarstvennykh sredstv [Costs of developing innovative drugs]. Center for Pharmacoeconomic Research. http://club.cnews.ru/blogs/entry/stoimost_razrabotki_innovatsionnyh_lekarstvennyh_sredstv

Belousov Yu.B. 2006. Innovatsionnyye lekarstvennyye preparaty v realnoy klinicheskoy praktike [Innovative drugs in real clinical practice]. $R C L, 38-43$

Buvailo A. 2018. Pharma R\&D Outsourcing Is On The Rise. BiopharmaTrend.com. https://www.biopharmatrend.com/post/30-pharma-rdoutsourcing-is-on-the-rise/

Conroy D., Conroy M. 2019. AI in Pharmaceuticals. Pharmaceutical Executive. http://www.pharmexec.com/ai-pharmaceuticals

Eremin S.Yu., Glembotskaya G.T. 2019. Rezervy povysheniya effektivnosti protsessa razrabotki novykh lekarstvennykh sredstv: pereprofilirovaniye lekarstvennykh preparatov i ispolzovaniye sovremennykh informatsionnykh tekhnologiy [Reserves to improve the efficiency of the new drug development: repositioning of drugs and the use of the modern information technologies]. Bulletin of the Bashkir State Medical University, 4: 89 - 98.

Ezekiel J. Emanuel. 2019. Big Pharma's Go-To Defense of Soaring Drug Prices Doesn't Add Up. The Atlantic. https://www.theatlantic.com/health/archive/2019/03/drug-prices-high-cost-research-and-development/585253/

Farm-giganty planiruyut ispolzovat blokcheyn dlya snizheniya stoimosti razrabotki lekarstv [Farm giants are going to use blockchain to reduce the cost of the drug development]. 2018. COINFOX. http://www.coinfox.ru/novosti/8557-farm-giganty-planiruyut-ispolzovatblokchejn-dlya-snizheniya-stoimosti-razrabotki-lekarstv

Frank R.G., Ginsberg P.B. (2017, November 13). Pharmaceutical Industry Profits And Research And Development. https://www.healthaffairs.org/do/10.1377/hblog20171113.880918/full/

Glembotskaya G.T., Eremin S.Yu. 2019. Nauchno-prakticheskiy podkhod k optimizatsii zatrat na razrabotku i prodvizheniye lekarstvennykh preparatov [Scientific and practical approach to optimizing the drugs development and promotion costs]. Bulletin of Roszdravnadzor, 3: 46-52.

Glembotskaya G.T., Ivanov S.V. 2017. Organizatsionno-ekonomicheskaya komponenta protsessa podgotovki novogo lekarstvennogo preparata $\mathrm{k}$ vyvodu na rynok [Organizational economic component of the process of preparing a new drug for the market launch]. Monograph. Scientific School of the Department of Organization and Economics of Pharmacy. Moscow, 385 - 425.

Global Data. (2017, October 4). Russia’s Pharmaceutical Market to Reach $\$ 36.61$ billion by 2021. https://www.globaldata.com/russiaspharmaceutical-market-reach-36-61-billion-2021/

Jain N. 2019. How precision medicine will change the future of healthcare. World Economic Forum. https://www.weforum.org/agenda/2019/01/why-precision-medicine-is-the-future-of-healthcare/

Jena A.B. 2018. US drug prices higher than in the rest of the world, here's why. The HILL. https://thehill.com/opinion/healthcare/369727us-drug-prices-higher-than-in-the-rest-of-the-world-heres-why 


\section{ENTREPRENEURSHIP AND SUSTAINABILITY ISSUES}

ISSN 2345-0282 (online) http://jssidoi.org/jesi/

2020 Volume 7 Number 4 (March)

http://doi.org/10.9770/jesi.2020.7.3(4)

Kazancheva O.D., Gerasimenko A.S. 2016. Metodologiya poiska novykh biologicheski aktivnykh farmakologicheskikh veshchestv s retseptornoy aktivnostyu [Methodology of searching for new biologically active pharmacological substances with receptor activity]. International Journal of Applied and Fundamental Research, 8(4): 522 - 525.

Kenton W. 2018. Capital Expenditure (CAPEX). Investopedia. https://www.investopedia.com/terms/c/capitalexpenditure.asp

Khonl A. 2013. Zatraty na razrabotku innovatsionnogo lekarstvennogo preparata [Costs of developing an innovative drug]. PUF, 2 (10): 52 $-54$.

Kolenov S. 2019. Farmatsevticheskiy II nauchili obkhodit patenty [Pharmaceutical AI learned how to bypass patents]. High-tech + . https://hightech.plus/2019/01/18/farmacevticheskii-ii-nauchili-obhodit-patenti

Motlagh H.N. 2018. A Paradoxical Trend in Drug Development. Medium|Atana. https://medium.com/atana/a-paradoxical-trend-in-drugdevelopment-481c62b59976

Nuzhnova, T.I., Gribova, Ya.V. 2013. Osobennosti razrabotki i vyvedeniya novogo preparata na rynok [Specifics of the development and launch of a new drug on the market]. Medical practice. http://mfvt.ru/osobennosti-razrabotki-i-vyvedeniya-novogo-preparata-na-rynok

Omelyanovsky V.V., Sura M.V., Sveshnikova N.D. 2011. Novyye lekarstvennyye preparaty. Kak otsenit innovatsionnost? [New drugs . How to evaluate innovation?]. Medical technology. Evaluation and selection, 1: $30-35$

Pogrebnyak A.V. 2013. Izucheniye novykh svoystv izvestnykh lekarstvennykh preparatov. Soobshcheniye I. teoreticheskoye obosnovaniye, polucheniye i issledovaniye novykh dezagregantov na osnove izvestnykh lekarstvennykh preparatov [Study of new properties of known drugs. Report I. Theoretical substantiation, obtaining and research of new disaggregants based on known drugs]. Pharmacy and Pharmacology, 1: $8-17$.

Pryor R., Cabreiro F. 2015. Repurposing metformin: an old drug with new tricks in its binding pockets. The Biochemical Journal, 471 (3): $307-322$.

Razrabotka novykh preparatov: skolko eto stoit na samom dele? [Development of new drugs: how much does it actually cost?] 2014. International Treatment Preparedness Coalition. https://itpcru.org/2014/12/26/razrabotka-novyh-preparatov-skolko-eto-stoit-na-samom$\underline{\text { dele/ }}$

Schuhmacher A., Gassmann O., Hinder M. 2016. Changing R\&D models in research-based pharmaceutical companies. Journal of Translational Medicine, 14(1). $\quad$ https://www.researchgate.net/publication/301667770_Changing_RD_models_in_researchbased_pharmaceutical_companies

Sholomitskaya M.M. 2013. Ekonomicheskaya otsenka i analiz innovatsionnogo razvitiya mirovoy farmatsevticheskoy promyshlennosti [Economic evaluation and analysis of the innovation-driven growth of the global pharmaceutical industry]. Economics and Banks, 2. https://cyberleninka.ru/article/n/ekonomicheskaya-otsenka-i-analiz-innovatsionnogo-razvitiya-mirovoy-farmatsevticheskoypromyshlennosti

Sullivan T. A 2018. Tough Road: Cost To Develop One New Drug Is \$2.6 Billion; Approval Rate for Drugs Entering Clinical Development is Less Than $12 \%$. Policy \& Medicine. https://www.policymed.com/2014/12/a-tough-road-cost-to-develop-one-new-drug-is26-billion-approval-rate-for-drugs-entering-clinical-de.html

Technology and Innovation for the Future of Production: Accelerating Value Creation. 2017. World Economic Forum. http://www3.weforum.org/docs/WEF_White_Paper_Technology_Innovation_Future_of_Production_2017.pdf

The pharmaceutical industry in figures. 2012. European Federation of Pharmaceutical Industries and Associations. https://efpia.eu/media/361960/efpia-pharmafigures2018 v07-hq.pdf

World Health Organization. Ten threats to global health in 2019. https://www.who.int/emergencies/ten-threats-to-global-health-in-2019 


\section{G.T. GLEMBOTSKAYA}

ORCID ID: orcid.org/0000-0002-4193-8973

\section{S.YU. EREMIN}

ORCID ID: orcid.org/0000-0003-4463-5369

\section{E.E. CHUPANDINA}

ORCID ID: orcid.org/0000-0003-2310-4198

Register for an ORCID ID:

https://orcid.org/register

Copyright (C) 2020 by author(s) and VsI Entrepreneurship and Sustainability Center

This work is licensed under the Creative Commons Attribution International License (CC BY).

http://creativecommons.org/licenses/by/4.0/

(c) (7) 